E N T R E V I S T A

\title{
ENTREVISTA COM MICHAEL HALL
}

\author{
Interview with Michael Hall
}

\section{CONCEDida A PAUlo FONTES E FRAnCisco Macedo}

São Paulo, 20 de julho de 2016

http://dx.doi.org/10.1590/S2178-14942016000300013

Paulo Fontes é professor da Escola de Ciências Sociais da Fundação Getulio Vargas (CPDOC/FGV), pesquisador bolsista produtividade do CNPq e editor de Estudos Históricos (paulo.fontes@fgv.br). Francisco Barbosa Macedo é professor do Instituto Federal Minas Gerais e doutorando do Programa de Pós-Graduação em História da USP (francisco.macedo@ifmg.edu.br).

Os entrevistadores agradecem a Fernando Teixeira da Silva e Antonio Luigi Negro pelas sugestões de questões e temas. Mônica Kornis recomendou a realização desta entrevista para Estudos Históricos. A ela também, nossos agradecimentos. 


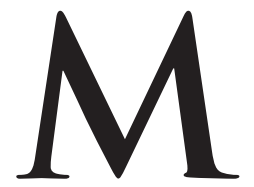

ichael Hall tem sido, nas últimas quatro décadas, um dos principais protagonistas da historiografia sobre o trabalho no Brasil. Nascido nos Estados Unidos em 1941, estudou nas Universidades de Stanford e Columbia, onde se especializou em história brasileira. Sua tese de doutorado, defendida no final dos anos 1960, tornou-se um dos textos fundamentais sobre a imigração italiana em São Paulo.

Em 1975 transferiu-se definitivamente para o Brasil e passou a lecionar na recém-criada Universidade Estadual de Campinas. Na Unicamp, foi uma das figuras centrais na construção do Departamento de História. Foi um dos fundadores do Arquivo Edgard Leuenroth (AEL), o maior arquivo especializado em história do trabalho na América Latina, e até hoje é um dos mais profundos conhecedores do acervo dessa instituição. Teve ainda importância fundamental na montagem da Biblioteca do Instituto e Filosofia e Ciências Humanas da Unicamp e na sua constituição como uma das principais bibliotecas de referência para pesquisa na área de ciências sociais e humanidades no país.

Especialista no estudo do anarquismo e do movimento operário na Primeira República, Michael Hall é um dos responsáveis pela difusão no Brasil da influente obra de E. P. Thompson e da historiografia social anglo-saxã. Desde os anos 1980, tornou-se uma espécie de "embaixador" da história social do trabalho brasileira, atuando como correspondente local de algumas das mais importantes revistas internacionais neste campo e sendo uma referência obrigatória para muitos pesquisadores estrangeiros em visita ao Brasil.

Orientador de diferentes gerações de historiadores, Michael sempre foi uma referência para seus alunos e colegas. 0 humor e ironia ferina, mas também as generosas e eruditas sugestões bibliográficas e dicas de fontes e acervos, invariavelmente redigidas em seu indefectível bloco de anotações de folhas amarelas, estão entre as melhores e carinhosas lembranças de todos(as) aqueles(as) que tiveram o privilégio de compartilhar sua convivência ao longo desses anos.

Aposentado desde 2012, Michael Hall continua ativo na pesquisa, orientação e participação em bancas de defesa de mestrado e doutorado. No momento prepara um livro reunindo ensaios e artigos antigos e suas pesquisas mais recentes. 


\section{Para começar, gostaríamos que nos falasse sobre suas origens, seus pais, onde você nasceu. Que nos contasse um pouco sobre o ambiente familiar no qual foi criado.}

Fui criado numa família de classe média em Houston, Texas, nos anos 1940 e 50. Meu pai era dentista. A única excentricidade era o fato de minha mãe ser assistente social, o que era um pouco progressista para o ambiente do bairro. Ela sempre alegava que era a única pessoa branca na nossa zona eleitoral que havia votado em Henry Wallace em 1948. ${ }^{1}$ Mas ela não era tão militante assim. Acho que realmente vim a conhecer uma outra realidade quando comecei a graduação em Stanford, que é uma universidade relativamente conservadora, ou certamente era, no começo dos anos 60. Mas os movimentos de direitos civis, pelo desarmamento nuclear etc. também atuavam lá, embora menos intensamente do que em algumas outras universidades, creio.

\section{Você foi fazer graduação em História em Stanford?}

Não. Ciência Política. Ninguém é perfeito. [risos] Mas acho que acabei fazendo quase o mesmo número de matérias de História e de Ciência Política.

\section{E por que um garoto veio do Texas para Stanford cursar Ciência Política?}

Primeiro, eu queria sair do Texas. Alguns colegas da turma anterior da high school que tinham ido para universidades da Ivy League - Yale, Princeton etc. - não estavam muito entusiasmados com a experiência, sentiam-se um pouco marginalizados. Já outros, que tinham ido para Stanford, ficaram um pouco mais animados.

\section{Em Stanford, então, você teve o interesse por História despertado. Lá também começou seu interesse pela América Latina?}

Sim, havia todo um ambiente, um clima em relação à Revolução Cubana, que despertava simpatias. As políticas da Aliança para o Progresso² eram bastante criticadas por alguns alunos da pós-graduação, e havia um professor, Ronald Hilton, um inglês meio excêntrico, que defendia até certo ponto a Revolução Cubana. Não tive muito contato com Hilton, mas na época ele atraía alunos de pós, de esquerda, do país inteiro. E isso também dava um foco. Mesmo sendo aluno de graduação, eu também ouvia essas pessoas. 


\section{E por que você foi fazer a pós-graduação em Columbia?}

Porque nos anos 60, nos Estados Unidos, Columbia era o lugar, se você estivesse interessado na América Latina. Cheguei em Columbia em 1963, no comecinho das agitações contra a Guerra do Vietnã, e comecei a conviver com um mundo realmente bem diferente daquele a que eu estava acostumado. Vários dos meus colegas e amigos eram os chamados crianças de fraldas vermelhas, filhos de ex-comunistas. E eu comecei a ficar cada vez mais horrorizado com a Guerra do Vietnã e interessado na América Latina. Na época, Columbia era um ótimo lugar para isso. 0 meu orientador, Lewis Hanke, nem era um cara muito político, e na verdade trabalhava com o período colonial. Era um bom sujeito, uma pessoa muito simpática e um bom historiador. Suas obras mais importantes são sobre Bartolomeu de Las Casas, mas ao redor dele havia um grupo grande de alunos interessados no Brasil: Joseph Love, ${ }^{3}$ Ralph Della Cava, ${ }^{4}$ Stuart Schwartz, ${ }^{5}$ que estavam um pouco à minha frente. E Peter Eisenberg, que me incentivava. E também havia várias outros professores em Columbia que trabalhavam com o Brasil, por exemplo, os antropólogos Charles Wagley ${ }^{6}$ e Marvin Harris. ${ }^{7}$ E havia vários alunos deles interessantes. Era um ambiente muito aberto. Acho que peguei um pouco desse ambiente.

\section{Em toda essa discussão sobre América Latina, como você começou a se interessar pelo Brasil? Sempre há a questão da língua.}

Sim, havia a questão da língua, e acho que na época também parecia um pouco exótico. Fiquei impressionado com o filme do [Jean-Paul] Belmondo, O homem do Rio, ${ }^{8}$ e também com o Orfeu Negro. ${ }^{9}$ E era uma época em que havia facilidade de obter recursos, bolsas de estudo para quem queria estudar a América Latina ou outros países do Terceiro Mundo. Então eu, que já havia passado um semestre na Itália e estudado italiano ainda na graduação, pensei que talvez fosse interessante estudar a imigração italiana no Brasil. Wagley estava muito entusiasmado com a ideia de italianos no Brasil, eu certamente sabia italiano melhor do que português na época, e então fiz o mestrado sobre isso. ${ }^{10} \mathrm{Fiz}$ o pouco que dava para fazer nas bibliotecas americanas, e em 1966 vim para cá.

\section{As fontes do seu mestrado estavam todas nos Estados Unidos?}

Sim, estavam. Foram vários panfletos sobre a imigração que localizei na Biblioteca Pública de Nova York, por exemplo. Materiais do século XIX. Propaganda, em parte, do governo 
imperial para incentivar e enganar imigrantes. Mas era um problema, porque de fato não havia tanto material desse tipo nas bibliotecas americanas.

\section{Em 1966, quando veio para o Brasil, você foi para São Paulo?}

Não. Para o Rio, primeiro. E passei seis meses, basicamente, na Biblioteca Nacional e um pouco no Arquivo Nacional. Também travei alguns contatos com acadêmicos. 0 pessoal da Cândido Mendes, Amaury de Souza, entre outros. Eu havia conhecido o Octávio lanni em Nova York, procurei-o em São Paulo, e ele me disse: "Ah, procure os meus amigos Sérgio Buarque e a Alice Canabrava, eles vão encaminhar você para as pessoas certas". E de fato. Todo mundo dizia que eu tinha que falar com a Emília Viotti da Costa, que conheci naquela época.

\section{Você sentiu alguma hostilidade por ser um pesquisador estadunidense, um "brasilianista"? Ou ao contrário, alguma facilidade?}

Hostilidade, nunca. Facilidade, não sei. Também não especialmente, acho. Na época havia sempre algumas pessoas fazendo denúncias. Lembro de um artigo do José Honório Rodrigues... ${ }^{11}$ E lembro de um episódio curioso. Havia uma mulher simpática, não vou lembrar o nome dela, na USIS, United States Information Service, ${ }^{12}$ que queria se aproximar de vários estudantes e pesquisadores americanos, e nós recusamos. E ela, acho, não entendeu muito. Mas 1966 já era o período da Guerra do Vietnã em que todo mundo, ou pelo menos a maioria de nós, queria se distanciar das políticas dos Estados Unidos no exterior.

\section{Havia uma certa comunidade de "brasilianistas" nessa época?}

Sim, vários. No Rio eu dividia com o Kenneth Erickson, ${ }^{13}$ cientista político, um apartamento no Posto Seis que era da embaixada da Suécia. As embaixadas ainda não tinham mudado para Brasília em 1966. Eles tinham esse apartamento simpático vazio, e o Ken, de família sueca, negociou o aluguel - tentando parecer o mais sueco possível, como ele dizia. E tinha muita gente no Rio, de fato. Peter Eisenberg, ${ }^{14}$ por exemplo, também estava pesquisando e veio com a Rosa, mulher dele. Era um ambiente muito simpático. Mas logo voltei para os Estados Unidos. Terminei a tese de doutorado. E perdi 1968 no Brasil. Mas voltei novamente em 1969, quando fiquei três meses. E então já era um ambiente bem mais sombrio. 


\section{E o que você fez logo que terminou a tese?}

Fui dar aula na University of North Carolina, que era uma "festa caipira" na época, pelo menos o Departamento de História. Eu sempre lembro que assinei uma declaração inócua da American Civil Liberties Union, ${ }^{15}$ e depois descobri que eu não só era a única pessoa dentro do departamento, mas praticamente o único professor na universidade a ter assinado a petição. Um dos professores de História veio conversar comigo fantasiado como fazendeiro pré-guerra civil, com terno de linho branco (isso certamente é imaginação minha), e disse: "A diferença entre você e nós, meu filho, é que nós defendemos a nossa pátria. Quando eu estava no Pacífico matando japas, eu nunca pensei em questionar meu comandante em chefe" ... Foi nessa época que eu inventei a "Lei de Hall", que não vale mais, pois a tecnologia mudou, com e-mail, Skype, Facebook, etc. Mas a lei concluía que quando a sua conta de telefone era maior do que o seu aluguel, você provavelmente estava morando no lugar errado. De qualquer forma, passei dois anos por lá. E depois fui para a Universidade de Tulane, em Nova Orleans. Achei que pelo menos eu estaria numa cidade interessante. Mas era um departamento bastante conservador também. E a cidade era boa para visitar, mas nem tanto para morar. Eu sempre imaginava que dentro daqueles prédios tão interessantes moravam pessoas igualmente interessantes, [risos] e não era o caso, pelo menos na minha experiência.

\section{E quanto ao Brasil? Depois você voltou novamente para cá.}

Sim. Eu tinha estado no Brasil em 1966, 67, fazendo a pesquisa de doutorado, depois voltei em 1969 e, de novo, em 1970. Depois fui pesquisar na Itália e voltei mais uma vez no começo de 1971, porque Carlos Guilherme Motta, que estava dando aula na Unicamp, havia me convidado para dar aula por lá, o que eu fiz entre março e junho daquele ano. Bem, em 1971, a barra estava mais pesada. Todo mundo precisava ser um pouco mais discreto. Ainda assim, a Unicamp, sendo uma universidade muito nova, provavelmente não era tão vigiada como a USP. Certamente, falando com pessoas da USP, a situação lá era bem mais grave, e várias pessoas estavam presas.

\section{Nesse contexto, você teve um certo papel no auxílio para o exílio da Emília Viotti da Costa, não foi?}

Emília me ajudou bastante em 1967, mas ela foi afastada da USP depois do Al-5 e sujeita a um processo absurdo graças a colegas do Departamento de História. Em 1970, 
deixei a minha vaga em Tulane aberta para Emília, o que era um pouco complicado. Joe Love tinha um amigo no consulado que deu o visto americano para ela, o que não era inteiramente tranquilo, porque ela estava sendo processada e tinha um passaporte brasileiro que iria vencer logo. Mas ela conseguiu entrar nos Estados Unidos e foi condenada à revelia. Posteriormente ela acabaria inocentada. Acho que em fins de 1971 ou começo de 1972, Joe Love convidou-a para dar aula em Illinois. Depois ela foi para o Smith College e, finalmente, para Yale, onde formou toda uma geração de especialistas em Brasil nos Estados Unidos.

\section{E quanto à Unicamp?}

Depois da experiência em 1971, voltei para os Estados Unidos. Tempos depois, Paulo Sérgio Pinheiro, ${ }^{16}$ que eu tinha conhecido então, insistiu muito para eu voltar para a Unicamp. Disse: "Faça um teste. Vamos arranjar uma bolsa Fulbright de professor visitante para você". Nessa época, 1975, a Unicamp era um lugar realmente atraente. 0 único problema inicial na Unicamp é que não tinha começado o Curso de História, então era História para cientistas sociais. Deve ter sido em 1977 ou 1978 que começou a graduação de História.

E eu, normalmente, oferecia uma disciplina de História Moderna ou de História dos Estados Unidos. Lembro que os alunos eram bastante politizados em comparação com os alunos americanos, ou pelo menos os da universidade sulista de Tulane. Logo depois da minha chegada, contratamos Peter Eisenberg. Ele estava dando aula em algum lugar do Caribe. A Unicamp era um lugar muito estimulante.

\section{E o clima político naquele contexto?}

Era 1975, 76, já no governo Geisel, mas prenderam pessoas da Unicamp. Lembro do Ademir Gebara, que era nosso colega do departamento. Isso era bem grave. E, claro, vários dos os professores da Unicamp estavam voltando do exílio. Havia os que tinham participado da luta armada ou os que tinham passado muitos anos na França. E a piada, minha e do Peter Eisenberg, é que eram esses caras que esperavam herdar o país, ex-líderes estudantis dos anos 60, que acabaram em Campinas, herdando um modesto Instituto de Ciências Sociais. Alguns tinham dificuldade em fazer os ajustes. Assim, muitas vezes as reuniões do Instituto se confundiam um pouco com as crises de ministérios em Paris ou Brasília. [risos] E havia algumas pessoas que, de fato, estavam na vida acadêmica um pouco por falta de outras opções, que teriam preferido carreiras políticas ou jornalísticas etc. Mas como essas não eram 
possibilidades realistas no período, elas acabaram na universidade, o que certamente tornou o ambiente político mais estimulante.

\section{Foi nesse contexto que foi criado o Arquivo Edgard Leuenroth, o AEL?}

Desde a minha rápida passagem de um semestre pela Unicamp em 1971, Paulo Sérgio Pinheiro e eu estávamos tentando estabelecer condições para a pesquisa em história do trabalho. Tínhamos alguns contatos com Germinal, filho do antigo líder anarquista Edgard Leuenroth. Ele estava ameaçando vender 0 arquivo do pai para a University of Texas, onde 0 filho do John Foster Dulles, John W. F. Dulles, ${ }^{17}$ era professor. Dulles tinha arrumado uma bolsa na Escola de Administração da University of Texas para o filho do Germinal. Eu fiz o contato para o Paulo Sérgio negociar com o Germinal, o que levou um certo tempo, porque ele queria receber mais ou menos o que ganharia da University of Texas. Mas o Paulo Sérgio estava preocupado e foi falar com o Zeferino Vaz, primeiro reitor da Unicamp. Ele acabou convencendo o Zeferino, que gostava de frases de efeito e disse: "Ah, vai ser minha obrigação, não só como reitor, mas como brasileiro, manter esse material no país". 0 resgate da documentação e as negociações para trazer o material para a Unicamp foram basicamente uma iniciativa do Paulo Sérgio. Eu não estava no país nesse período. Só cheguei em 75, quando o arquivo já estava assegurado. Criar um arquivo para a História Social, e especialmente para o movimento operário, era uma grande aspiração do Paulo Sérgio. Algo em bastante sintonia com o espírito dos anos 60, começo dos anos 70.

\section{É curioso. Na mesma época em que o CPDOC da FGV estava sendo criado como um arquivo, digamos, dedicado à elite política brasileira, a Unicamp estava criando um arquivo do movimento operário, de História Social.}

Sim. Mas nunca consegui convencer nenhum diretor do AEL a fazer para o movimento operário o que o CPDOC fez para a elite política, um grande projeto de História Oral, de entrevistas com trabalhadores e líderes sindicais. Porque em 1975 havia muitos sobreviventes dos anos 30,40. No início, houve certa dificuldade para institucionalizar o arquivo, por inércia burocrática. Não havia professores com tempo exclusivo para dirigir o arquivo, nem muitos recursos. Dando aula, não dava para investir tanto tempo. E até a chegada do Marco Aurélio Garcia, ${ }^{18}$ no início dos anos 1980, não havia, de fato, um diretor do arquivo. 


\section{Há um certo "mito", digamos assim, do período inicial da Unicamp como um espaço da dissidência, da diferença em relação à tradição acadêmica brasileira, em particular em relação à USP. Você poderia comentar um pouco esse momento da década de 1970 ?}

Havia várias pessoas da USP no início da Unicamp: Carlos Guilherme Mota, Fernando Novais, sobretudo. Mas é verdade. A Unicamp aparecia como algo relativamente diferente e, talvez, menos vigiado. Eu acho que, em parte, isso se deve ao fato de que Zeferino ${ }^{19}$ contratou pessoas jovens. Muitos com formação no exterior, e não apenas na Europa. Evelina Dagnino ${ }^{20}$ e alguns outros, por exemplo, formados nos Estados Unidos. Um pouco depois dela, veio Bela Feldman-Bianco, que havia estudado Antropologia em Columbia. E claro, a USP havia sofrido as cassações, as aposentadorias obrigatórias do Al-5. A Unicamp tinha uma abertura para o mundo, por causa da formação dos professores e de um número razoável de estrangeiros, o que não era muito comum nas outras universidades brasileiras na época.

\section{Mas havia uma rivalidade com a USP?}

Ah. Não, não era uma rivalidade, exatamente. O Departamento de História da USP era sempre um pouco mais problemático do que os outros departamentos da Faculdade de Filosofia. Por motivos que nunca entendi, aliás. Mas, na verdade, acho que havia um pouco de deferência à USP. Muitos professores da Unicamp haviam estudado na USP, pelo menos na graduação. E a repressão das outras universidades no resto do país tinha sido terrível. Então, realmente, mal existiam Ciências Humanas fora da USP e da Unicamp, ou do IUPERJ no Rio. Um momento interessante foi um congresso internacional organizado pelo Paulo Sérgio Pinheiro na Unicamp em 1975. ${ }^{21}$ O congresso contou com a presença de Eric Hobsbawm, Arno Mayer, Juan Linz, Guillermo O'Donnel, Rudolf de Jong, do Instituto de História Social de Amsterdã, e várias outras pessoas. Arno Mayer estava espantado com a realização do evento e comentou: "Mas é muito curioso, no meio dessa ditadura.... É um pouco como a França da Restauração. Dentro do salão, se pode dizer qualquer coisa, sem muito medo". E a Unicamp era um pouco isso, também. Não havia grandes inibições sobre o que se usava como leitura, o que se falava em sala de aula. E tudo era muito interdisciplinar. E muito autogestionário também. Nos tomava um tempo incrível em reuniões, mas havia um espírito simpático, que não parecia muito comum no Brasil na época. 
Você acha que acabou havendo uma associação da "novidade" que a Unicamp representava com o processo de redemocratização, com o "novo sindicalismo", com todo aquele contexto do final dos anos 70 ?

Acho que sim. Tinha um pouco disso, certamente. No mínimo, tinha uma abertura para isso.

Em contraste com a USP, que teria um certo peso da "tradição".

Sim. Embora eu ache que seja importante distinguir os departamentos de Ciências Sociais e de Letras do Departamento de História, na USP. Fora do Departamento de História, me parece que havia bastante engajamento e agitação.

É interessante, porque boa parte dos contatos dos historiadores da Unicamp que estudavam o movimento operário com a USP se dava com as Ciências Sociais: Eder Sader, $^{22}$ Maria Célia Paoli, ${ }^{23}$ Vera Silva Telles, ${ }^{24}$ entre outros. Como se dava esse contato? Por exemplo, como você conheceu Maria Célia Paoli?

Ao que me lembre, foi no Cedec $_{1}{ }^{25}$ que era um espaço estimulante, inicialmente com sede num prédio ao lado da PUC, e tinha pessoas interessantíssimas. Maria Vitória Benevides, $^{26}$ Francisco Weffort ${ }^{27}$ e vários professores visitantes passaram por lá. Eu acho que foi lá que eu conheci grande parte das pessoas da USP.

Sendo um historiador que estava estudando a classe operária, como você vivenciou as greves do $A B C$ paulista no final dos anos 70 e toda a efervescência sindical e política daquele período?

Muito indireta e distantemente, de fato. Só lendo jornal e falando com as pessoas. Em parte, pela nacionalidade, eu não queria me intrometer muito. Mas era uma satisfação ver que as ortodoxias da sociologia brasileira sobre o assunto estavam visivelmente erradas. [risos]. De toda forma, foi um período de enorme entusiasmo entre professores e alunos na Unicamp.

E isso se refletia no interesse dos alunos pela história do trabalho?

É muito curioso. Na época, vários alunos estavam interessados no material do Arquivo Edgard Leuenroth. Por uma série de motivos. Alguns, para comprovar a superioridade de 
partidos leninistas e como os anarquistas estavam errados. E de fato, um pouco nesse espírito, saiu pelo menos um bom livro, que é o da Silvia Magnani. ${ }^{28}$ Mas era um período político em que os alunos de fato fizeram algumas passagens bruscas de Petrogrado para São Paulo. [risos] Eu me lembro de uma grande discussão, em que eu estava tentando argumentar que as adversidades e rivalidades até regionais entre os italianos, além das hostilidades em relação a outros grupos nacionais, tinham criado obstáculos sérios para o movimento operário e fui duramente criticado, porque a "ciência científica do marxismo-leninismo" tinha, cientificamente, comprovado que as relações com os meios de produção haviam determinado as práticas dos trabalhadores, e que esses outros elementos eram, portanto, só mistificações. Então, publiquei um artigo em inglês sobre o assunto - acho que foi a primeira coisa que escrevi sobre movimento operário - em uma revista alemã ${ }^{29}$ o que garantia total desconhecimento desse artigo no Brasil [risos].

\section{Alguns anos depois você publicou um artigo em parceria com Paulo Sérgio Pinheiro, "Alargando a história da classe operária", ${ }^{30}$ que já era claramente inspirado na História Social britânica. Como foi sua aproximação pessoal com a História Social britânica?}

De fato, nos anos 60 era um pouco frustrante, porque a história do movimento operário em geral era, nos Estados Unidos pelo menos, uma história política sindical, narrativa, sem muito interesse. Eu me lembro apenas dos artigos de Gutman, ${ }^{31}$ que achei muito interessantes na época, mas não havia muito mais que isso facilmente disponível. Minha lembrança é que li pela primeira vez A Formação da classe operária inglesa de E. P. Thompson em 1969. Achei muito interessante e muito difícil, porque, para quem não está muito por dentro da história inglesa, não é um livro fácil de entender em detalhes. Mas achei fascinante, intrigante. Paulo Sérgio chegou a Thompson via autores franceses, Michelle Perrot e George Haupt, alguns dos quais tinham sido seus professores em Paris. Mas só bastante depois, nos anos 70, eu fui ler outros historiadores ingleses. Lembro que na Unicamp assumi uma disciplina sobre História Moderna para me obrigar a ler Christopher Hill. ${ }^{32}$

Mas na Unicamp, Verena Stolcke ${ }^{33}$ e o marido, Juan Martinez-Alier, estavam muito por dentro da esquerda inglesa do período e tinham muita simpatia. Verena, certamente, estava sempre bastante dedicada a mostrar os trabalhadores como agentes da sua própria história. Porque a tendência na Unicamp em geral era derivar tudo de certas noções de modos de produção ou do movimento do capital, o que deixava uma impressão bastante mecânica do que deveria ser a história dos trabalhadores. Paulo Sérgio e eu publicamos aqueles livros 
de documentos, ${ }^{34}$ um pouco no espírito de contestar essa visão. Aliás, a primeira versão de algumas dessas ideias do artigo que você mencionou está na introdução do primeiro volume de documentos. Mas a preocupação também era darmos certa legitimidade acadêmica a esse tipo de História Social. 0 que havia sobre a história do movimento operário no Brasil, até 0 final dos anos 70, eram livros de militantes, o do Everardo Dias sendo o mais interessante..$^{35}$ E também alguns trabalhos de sociólogos - o melhor, certamente, é o de Azis Simão. ${ }^{36}$ E os sociólogos geralmente não estavam tão interessados no movimento sindical pré-1930. 0 que eles queriam era criticar o populismo. Então o espírito do que eles escreviam sobre 0 movimento operário anterior a 1930, para simplificar um pouco, era "olha essa beleza que o populismo estragou". E fora o Azis Simão, a familiaridade dos sociólogos com o movimento operário da Primeira República não era grande.

Acho que Paulo e eu queríamos, de um lado, tentar fazer uma reconstituição do movimento operário naquele período e, de outro, tentar levantar questões thompsonianas de agência. E tinha um grupo na Unicamp aberto a isso. Acho que o papel da Verena Stolcke foi muito importante. Porque aquele artigo que eu escrevi com Verena ${ }^{37}$ sobre 0 colonato era em parte aplicando algumas ideias dela sobre a capacidade e atuação dos colonos para resistir à exploração que sofriam. E escrevemos esse artigo no fim dos anos 70, que era um momento em que eu tinha muito mais clareza sobre o que queria fazer. E sempre havia alguns alunos abertos a isso. Além do mais, a conjuntura política e sindical daquele período ajudava a dar legitimidade a esse tipo de abordagem.

\section{E Eric Hobsbawm? Você leu Hobsbawm nessa época?}

Eu tinha lido os primeiros livros dele, o Rebeldes primitivos e o A era das revoluções, relativamente cedo, no começo dos anos 60, e fiquei muito impressionado. Anos depois, conversando com Verena, que o conheceu bem na Inglaterra, comecei a compartilhar a crítica bastante convincente que ela tinha em relação ao Rebeldes primitivos. E que também era uma crítica em termos disciplinares. Sendo antropóloga, ela tinha reservas explícitas.

\section{Ele era mais conhecido nos Estados Unidos?}

Não, de fato. E tenho aquela história com um professor que tive na Universidade - isso seria 1963 - quando mencionei Hobsbawm, e ele me respondeu: "Ah, Hobsbawm. Muito interessante. Mas muito perigoso". Certamente deve ter sido ironia. Mas, de fato, Hobsbawm era um pouco marginal entre os historiadores profissionais nos Estados Unidos, pelo menos no começo dos anos 60. 


\section{Como foram suas primeiras tentativas de introduzir os textos de E. P. Thompson entre os alunos da Unicamp?}

Em meados dos anos 1970, antes de existir a pós em História na Unicamp, eu e o Paulo Sérgio oferecemos um curso na Ciência Política e usamos um capítulo de $A$ Formação pela primeira vez. Esse momento era 0 auge do althusserianismo, especialmente entre o pessoal da Ciência Política e da Sociologia. Até o Paulo Sérgio tinha sido aluno do Nicos Poulantzas em Paris, e Décio Saes e vários outros estavam lá na Unicamp, muito influenciados pelos escritos de Althusser. Portanto, o nosso curso era um mini escândalo. Não sei quantos alunos vinham do Partido Comunista, mas alguns davam pequenas aulas de ortodoxia leninista para nós. Era muito estranho, porque a reação ao Thompson era uma mistura de incompreensão e indignação dos alunos. Parte do problema era que eles não eram historiadores. Então, estavam também muito preocupados com o perigo da "contaminação pela empiria". Eu me lembro de uma aluna que me disse, com toda a indignação: "Professor, eu fiz o curso de História da Universidade de São Paulo e esse negócio de empiria... francamente, é uma fase que eu já ultrapassei". [risos]. E indignação do tipo, "mas onde está o capítulo onde ele explicita seus pressupostos teóricos e metodológicos?" Depois, quando voltei da Alemanha, no começo dos anos 1980, eu me lembro de usar Thompson na pós em História, e a receptividade foi muito maior.

\section{E essa experiência na Alemanha? Como é que você foi parar em Berlim Ocidental no início dos anos 80 ?}

Eu fui porque Robert Conrad, ${ }^{38}$ que tinha sido meu colega em Columbia, era professor por lá. Ele falava alemão e era casado com uma alemã. Mas se envolveu numa briga feia dentro do Instituto da América Latina e pediu demissão. Com isso, Manfred Nitsch, que era diretor do Instituto, me convidou para ficar um semestre como professor visitante, já que era possivel dar aulas em inglês. Depois surgiu uma vaga, e me convidaram para ficar mais um semestre. Então fiquei um ano letivo inteiro por lá. Nos primeiros meses em Berlim, eu me envolvi muito na elaboração do capítulo sobre história do movimento operário na América Latina da Cambridge History. ${ }^{39}$ Eu tive que estudar bastante, pois não sabia tanto sobre o movimento operário em outras partes da América Latina. Mas havia um grupo ótimo no Instituto da América Latina. 0 espírito de 1968 estava presente entre uma parte dos professores mais jovens. Foi uma boa experiência, porque eu não tinha envolvimento burocrático nenhum, então tinha tempo para estudar; e dei aulas sobre assuntos que me 
interessavam. Berlim Ocidental era uma cidade muito curiosa, na época, ainda com o muro. E havia um monte de exilados, chilenos, argentinos e alguns brasileiros, o que também dava um toque estimulante.

\section{Você chegou a ir a Berlim Oriental?}

Várias vezes. Uma vez fui ver a peça O Sr. Puntila e seu criado Matti, de Brecht, no Berliner Ensemble e entendi cinco por cento, mas eu tinha lido a peça em inglês antes. E lembro de um brasileiro ex-comunista, que eu não vou dedar aqui [risos], com quem fui passear em Berlim Oriental. Ele me disse: "Próspero demais para país comunista" [risos]. Mas eu lamento não ter ido com um grupo que foi até a Polônia, que ficava a cem quilômetros de Berlim, no auge do Solidariedade. Os brasileiros e argentinos do grupo que foi voltaram com observações curiosas, do tipo: "É um movimento nacionalista polonês, antissemita, extremamente católico..." Um dos argentinos disse: "Eu nunca tinha visto tantos homens adultos numa igreja, na minha vida". [risos] Mas logo depois veio o fechamento do Solidariedade.

A impressão que temos é de que, a partir dos anos 1980, você passou a ser uma espécie de "embaixador da História Social do Brasil". Muitos americanos e europeus interessados no tema vinham à Unicamp conversar com você, e alguns, com a sua ajuda ou influência, ficaram para dar aula. Você virou correspondente no Brasil de revistas internacionais importantes no campo da história do trabalho, como a International Labor and Working Class History, dos Estados Unidos, e a International Review of Social History, do International Institute of Social History de Amsterdam. Como você vê isso?

Não sei. Não acho que era exatamente assim. Eu não tinha nenhuma consciência objetiva nisso, simplesmente aconteceu. Acho que não tinha isso claro.

Por outro lado, você sempre estimulou fortemente seus alunos a estabelecer contatos e conexões internacionais, e seu próprio trabalho tem esse viés...

Isso é verdade. Mas não sei exatamente por que eu tendo a pensar questões históricas em termos de comparação. Mas é verdade, eu faço isso muito. 


\section{De toda forma, as pessoas o procuravam, e a Unicamp passou a receber professores visitantes, como David Montgomery, ${ }^{40}$ Barbara Weinstein, ${ }^{41}$ Daniel James, ${ }^{42}$ entre outros.}

Sim, mas é curioso. Montgomery, por exemplo, veio graças à iniciativa da antropóloga Bela Bianco, que o havia conhecido em Yale e incentivou muito a vinda dele. Fizemos os trâmites burocráticos, mas quem estava por trás disso era a Bela. E Montgomery se deu muito bem aqui. Chegou num momento perfeito, também, em que havia muita abertura e interesse pelo tipo de trabalho que ele estava fazendo. 0 ambiente na Unicamp tinha mudado, especialmente entre os alunos de História, com uma maior abertura para o tipo de História Social feita pelo Montgomery, por exemplo. Nesse sentido, a chegada dos professores que estudavam a escravidão colaborou bastante. Bob Slenes, ${ }^{43}$ Silvia Lara, ${ }^{44}$ Sidney Chalhoub, ${ }^{45}$ Clementina $^{46}$ também. E a vinda do Claudio Batalha, ${ }^{47}$ que deve ter sido em 1986, reforçou enormemente a área de história do movimento operário, porque ele tinha acabado de fazer uma tese sobre 0 sindicalismo reformista no Rio e tinha imensa familiaridade com as fontes.

\section{Em que sentido?}

Nós compartilhávamos as mesmas preocupações metodológicas e mesmo muitas questões de pesquisa. Apesar da tradição de colocar a escravidão e o movimento operário em campos de estudos diferentes - e a Silvia Lara logo começou a demolir essa tradição. As leituras do Thompson eram um campo comum, em particular os artigos mais acessíveis para quem não era especialista em história inglesa, sobretudo "A economia moral da multidão" ${ }^{48}$ Thompson não explicita muito, talvez por motivo de solidariedade, mas o artigo era uma crítica devastadora ao Rebeldes primitivos de Hobsbawm e até aos trabalhos do George Rudé. ${ }^{49}$ 0 pessoal aqui entendeu o recado, talvez com mais precisão do que nos Estados Unidos, porque cabia muito bem nas discussões que fazíamos na Unicamp na época. Outro artigo do Thompson que usávamos e que provocou muita discussão é o "Class struggle without class" ${ }^{50}$

\section{Por outro lado, na Unicamp, nessa época, também estava crescendo a influência de Foucault. Alguns chegam a dizer que houve uma certa mistura eclética entre Thompson e Foucault.}

Verdade. Estranhíssimo. Acho Foucault um homem muito interessante, mas nunca entendi politicamente o que as pessoas que se diziam, por exemplo, simpatizantes do 
anarquismo, viam num homem que não dava espaço para alguma atuação política consequente. Eu levantei essa questão numa defesa de tese na Unicamp, mas acho que o aluno ficou mais com Foucault. [risos] Foucault anarquista só no Brasil!

Gostaria de saber um pouco da sua experiência "pública". No gestão de Luiza Erundina na Prefeitura de São Paulo (1989-1992), muitos professores da Unicamp, da USP, da PUC-SP, acabaram tendo uma atuação importante na Secretaria de Cultura, então comandada por Marilena Chauí. Você também colaborou um pouco, não?

Sim. Perseguindo bibliotecários. A minha especialidade... [risos] Marilena Chauí havia arrumado com o Paul Singer, então secretário de Planejamento da Prefeitura, uma enormidade de dinheiro, algo como cinco milhões de dólares, para as bibliotecas públicas, e as bibliotecárias, sem experiência de compras em grande escala, simplesmente iam devolver o dinheiro. E eu já havia começado essa missão na biblioteca da Unicamp e entendia um pouco os meandros das compras internacionais. Então, organizei um grupo de especialistas para tentar escolher livros para as bibliotecas municipais, e passei muito tempo tentando mobilizar as bibliotecárias etc. 0 grosso das compras era de livros nacionais, para as na época 80 bibliotecas públicas. E depois compramos de Portugal, Espanha, Argentina, e posteriormente da França, e obras de língua inglesa. Mas, de fato, essa última compra dos livros em língua inglesa foi via Fapesp, porque Marilena conseguiu convencer a Fapesp a permitir que a Biblioteca Mario de Andrade entrasse na competição do programa Faplivros. Ela argumentou que a Mario de Andrade, sem ser um departamento universitário, era inquestionavelmente uma instituição de pesquisa no estado de São Paulo. E eles aprovaram. Não me lembro quanto, exatamente. Mas foi uma quantidade significativa. Em geral, era muito complicado fazer as compras da Secretaria de Cultura num período de inflação alta e com pessoas sem muita experiência. Mas foi muito gratificante também. $E$, de fato, deu certo. Acho que foi a coisa mais útil que eu fiz no Brasil.

\section{Você falou em missão. Transformar a biblioteca do IFCH da Unicamp em uma grande biblioteca de pesquisa foi uma das características da sua carreira. Por que você, particularmente, se dedicou a isso?}

Eu entrei nisso, em parte, forçado. Eu me lembro de uma conversa com Peter Eisenberg, em 1976 ou 77, em que fazíamos uma avaliação do trabalho na Unicamp. Lembro de 
comentarmos que poderíamos gostar de alguns dos colegas mais que de outros, mas que todos os professores trabalhavam num nível internacional. As instalações físicas poderiam ser um pouco melhores, mas não atrapalhavam o funcionamento do Instituto. 0 grande choque era a falta de biblioteca decente. Porque havia dinheiro, nos anos 70, mas as bibliotecárias e a burocracia da Unicamp em geral não conseguiam gastar. E as bibliotecárias não sabiam muito o que pedir. Mas, de fato, eu só entendi bem o processo todo no início dos anos 1980: era necessário acompanhar todos os detalhes da compra para conseguir comprar livros de forma adequada. Então, comecei a me dedicar a motivar os colegas para ajudar na seleção de livros e tentar lidar com os problemas administrativos, identificando as bibliotecárias competentes e motivadas, e acabei me especializado nesses processos de compra de livros e montagem de biblioteca. Mas é sempre um choque, eu acho, nas universidades brasileiras, ver que as bibliotecas estão entre as deficiências mais gritantes. E, falando francamente, também, me dediquei a isso para não ter que ser chefe do departamento ou coordenador de pós, etc. Eu podia sempre alegar que o meu tempo disponível estava dedicado à perseguição de bibliotecárias. [risos]

\section{Gostaríamos de explorar agora o seu próprio trabalho, sua obra e suas opiniões sobre alguns aspectos da história do trabalho e da historiografia em geral. Identificamos três eixos, digamos, "clássicos" do seu trabalho: a imigração, 0 movimento operário na Primeira República e a cidade de São Paulo como o local prioritário de interesse para essas análises. Você poderia dar um panorama da sua obra, articulando seus trabalhos e interesses com sua própria trajetória?}

Bem, no início da carreira minha ideia era fazer algo sobre os italianos no movimento operário no Brasil, mas como na época da tese de doutorado eu não tinha conseguido acesso a muitas fontes, acabei escrevendo sobre o colonato, basicamente com fontes italianas. O grande argumento, eu suponho, era mostrar como, de fato, a imigração subsidiada foi usada para manter os colonos desorganizados e facilmente explorados. Mesmo sem ter uma intenção muito explícita por parte dos fazendeiros, esse foi certamente o efeito. Nesse sentido, a tese era uma reação contra algumas afirmações celebratórias do liberalismo da Primeira República. Quando você pensa que o preço do café foi manipulado via valorização, os salários dos colonos via imigração subsidiada, e que a polícia também foi usada brutalmente em grande escala para impedir a organização operária, isso não é o liberalismo que se lê nos manuais, para dizer o mínimo.

Há também um aspecto do trabalho, que ainda não publiquei muito, referente a greves de colonos. Em parte é fruto do meu trabalho conjunto com Verena Stolcke. Tentamos 
contestar vários historiadores que insistem na inexistência da capacidade política dos colonos. Boris Fausto tem um parágrafo no fim do livro dele sobre a Revolução de 30, ${ }^{51}$ falando da ausência de casos significativos de mobilização e organização no campo durante a Primeira República, com a exceção de alguns movimentos messiânicos. E Verena e eu mostramos dez mil colonos em greve na região de Ribeirão Preto em 1913. Há vários outros movimentos desse tipo. Mas o pior argumento é o de um americano cubano, Mauricio Font, 52 que menosprezou as greves dos colonos afirmando que afinal eles eram menos organizados e militantes que os camponeses no meio da Revolução Mexicana, ou os trabalhadores chilenos nas minas de salitre. Isso é claramente - como se diz? - estabelecer a barra um pouco alta demais... [risos] De toda forma, acho que estávamos tentando também desmitificar a noção de que os imigrantes estavam escolhendo livremente o Brasil. Eles vieram porque estavam desesperados e o Brasil era o único país que pagava passagem integralmente em grande escala. Como estava interessado no movimento operário, eu queria ver como a imigração parece ter, e de uma maneira complexa, incentivado e atrapalhado práticas consequentes dos trabalhadores. Claro, havia inúmeros obstáculos, em São Paulo, ao movimento operário organizado; não só a repressão, mas um mercado de trabalho inundado de imigrantes, o que tornava o uso da greve muito difícil como arma. Além disso, os imigrantes formavam grupos bastante divididos, de diferentes origens geográficas; havia hostilidades não só entre portugueses, espanhóis e italianos, mas entre italianos do sul e italianos do Veneto e de outras regiões.

\section{A historiografia mais contemporânea tem destacado muito a questão do pós- abolição, do papel dos negros, da relação dos "nacionais" com os imigrantes. Você não chegou a explorar isso nos seus trabalhos, mas como você vê essa questão?}

Pois é. Achei coisas interessantes a esse respeito, mas apenas entrei um pouco nessa questão em dois artigos mais gerais ao abordar os movimentos anti-italianos em São Paulo no começo dos anos $1890 . .^{53}$ A primeira constatação foi que a população negra da cidade de São Paulo não cresceu muito depois da abolição. Se você analisa os recenseamentos de 1886, 1890 e 1893, nos quais a raça era registrada, de fato a população negra não aumentou muito, chegando a $11 \%$ em 1893. Mas no grande movimento contra os italianos, dos chamados "jacobinos", há uma grande presença negra. É possível perceber a continuidade do abolicionismo mais militante em São Paulo, que desembocou no jacobinismo. Há, obviamente, ressentimentos da parte dos ex-escravos e seus descendentes em relação aos italianos que estavam ocupando lugares de trabalho que eles consideravam seus. Ao mesmo tempo, sempre tento me perguntar: que diferença fez essa imigração maciça em São Paulo? Um dos efeitos, 
certamente, foi que ela prejudicou seriamente os ex-escravos e seus descendentes. Mas é difícil saber se ela empurrou São Paulo e o Brasil em outras direções que não teriam sido tomadas sem a imigração em grande escala.

0 artigo famoso do Bresser Pereira ${ }^{54}$ sobre as origens nacionais dos donos de grandes empresas, supostamente mostrando a importância dos valores "empresariais" de imigrantes no crescimento econômico de São Paulo, é muito discutível. De fato, a composição da população da cidade de São Paulo, em termos de pais ou avós imigrantes, não é muito diferente da amostra dele de empresários de origem estrangeira. Os "brasileiros de duas gerações", que Bresser argumenta não mostraram as mesmas qualidades de inovação e iniciativa dos imigrantes e seus descendentes, precisam de investigação. Na época da pesquisa de Bresser, esse grupo teria incluído muitos migrantes nordestinos recentes, que, mesmo incorporando as melhores qualidades empresariais, não teriam tido condições de entrar numa amostra da elite empresarial em 1962. E nenhum observador que conheço achava a Itália, Portugal e Espanha, países de origem da imensa maioria dos imigrantes em São Paulo, exatamente paraísos do espírito do capitalismo no fim do século XIX. E há observadores que mencionam, ao menos em relação aos portugueses, que estes seriam muito pouco empresariais, hostis à inovação e um obstáculo ao desenvolvimento. Então, esse tipo de pergunta sobre o efeito de longo prazo da imigração é difícil de responder.

\section{Durante muito tempo as pesquisas sobre história do trabalho diziam estar abordando o Brasil, mas na verdade estavam falando de São Paulo e do Rio. Mais recentemente, com o desenvolvimento da historiografia em outras regiões, podemos ter uma perspectiva mais nacional de fato. Considerando toda a sua pesquisa sobre imigração e movimento operário na Primeira República, você diria que caso de São Paulo é peculiar, no conjunto do país?}

Eu diria primeiro que, apesar dessa generalização feita a partir da experiência paulista, acho que São Paulo é, de fato, a grande exceção. Porque em São Paulo havia uma burguesia relativamente consolidada e uma luta de classe clara e explícita, o que não era o caso no grosso do resto do país. Em vários outros lugares, por exemplo, você encontra, nas greves, o governo local e a polícia frequentemente negociando com os grevistas, algo que teria sido quase inconcebível em São Paulo. Não sei até que ponto isso se deveu à imigração, especialmente. Ninguém conseguiu relacionar esses aspectos muito claramente. Há dois argumentos contraditórios sobre a imigração e a industrialização. Há a ideia de que os imigrantes serviram como um exército de reserva propiciando a acumulação, o que não combina muito bem com 0 
argumento dos imigrantes como consumidores fornecendo o estímulo necessário para o crescimento industrial. Os escravos são notoriamente maus consumidores, é verdade; mas duvido que os colonos dos anos 1890 e começo do século XX tenham estimulado o mercado interno tanto assim. É difícil avaliar isso. A outra questão, que alguém tem de estudar com mais precisão - embora haja um bom artigo do José de Souza Martins ${ }^{55}$ a respeito - está relacionada à existência de uma grande burguesia italiana em São Paulo, o que nos Estados Unidos, por exemplo, teria sido inconcebível no mesmo período. Martins argumenta que, com uma ou outra exceção, esses empreendedores vieram com algum dinheiro ou conexões com interesses estrangeiros (como Matarazzo, por exemplo), o que permitiu investimentos rápidos, especialmente na indústria têxtil. Mas, sem dúvida, é necessário mais pesquisas sobre esse aspecto...

Se a sua hipótese é de que, de uma maneira complexa, a imigração ajudou e dificultou a organização, você consegue ver que tipo de organização poderia estar sendo atrapalhada pela imigração?

Acho que a primeira coisa a constatar é que você não vai encontrar muita experiência industrial ou experiência política anterior em uma imigração incentivada de pessoas desesperadas saindo de regiões rurais. Havia alguns militantes com experiência política na Itália, mas eles eram algumas dúzias numa imigração italiana de quase um milhão de pessoas. Esta é realmente uma questão contrafactual muito difícil. Porque, para os militantes políticos, os ex-escravos e seus descendentes não pareciam um terreno mais promissor politicamente do que os camponeses desesperados vindos do Vêneto.

Sua pesquisa sobre greves de colonos e organização dos trabalhadores rurais na Primeira República, feita em conjunto com Verena Stolcke ${ }^{56}$ e que você já mencionou, possui um certo pioneirismo, pelo menos em termos de historiografia brasileira. Na historiografia internacional há toda uma discussão sobre os coolies, levantada em especial pelos historiadores indianos; ou seja, há uma ênfase na análise de formas de relação de trabalho que geram forte dependência, que não são exatamente assalariadas, mas também não são escravas. ${ }^{57} 0$ que você acha desse debate? Há autores que chegam a sugerir que os colonos poderiam ser uma espécie de coolies. Como você vê isso?

De fato, meu artigo com Verena tinha dois objetivos. 0 primeiro era o de criticar as interpretações do colonato como algo pré-capitalista ou não capitalista. As relações eram 
um pouco específicas de São Paulo no período, é verdade. Sobretudo por causa da presença nas fazendas de terras que não eram propícias para o café, mas podiam ser cedidas para os colonos cultivarem feijão, milho, etc. Assim, os fazendeiros pagavam um salário mais baixo ao disponibilizar para os colonos um terreno sem muito valor econômico para eles próprios. Isso pode soar estranho, mas é totalmente compatível com o capitalismo, assim como outros aspectos, os contratos de um ano, por exemplo. Nada disso era desconhecido para os capitalistas. E a minha impressão é que é difícil negar que os colonos estavam vendendo sua mão de obra no mercado para os fazendeiros. Os termos desse tipo de relação variavam mundialmente. E em São Paulo as condições eram muito desfavoráveis aos trabalhadores. Então os fazendeiros conseguiram impor algumas condições que parecem anomalias no capitalismo. Mas acho que isso é, simplesmente, a consequência da posição de barganha dos dois lados.

O segundo objetivo do artigo era demonstrar a capacidade de resistência dos trabaIhadores rurais. Por exemplo, o fracasso dos esquemas de parceria mais cedo, no século XIX, aconteceu por causa da resistência dos parceiros, e não porque os colonos eram a "escória da Europa", recrutados por agentes pouco escrupulosos etc... Por incrível que pareça, esse era um argumento muito comum na historiografia. Procuramos mostrar que, de fato, apesar de toda uma série de elementos desfavoráveis, os colonos conseguiram impor alguns limites à sua exploração. Claro, isso tem uma certa semelhança com os estudos mais recentes da escravidão, que mostram mecanismos parecidos.

\section{Mas a primeira parte do argumento, de que esses tipos de relações de trabalho são possíveis no capitalismo, é similar ao argumento dos indianos sobre os coolies.}

Isso é verdade. Mas nós não entramos nisso, por ignorância, na época. Hoje talvez fosse um tema de diálogo, embora minha impressão seja de que os colonos eram bem mais livres que os coolies, tanto na teoria como, sobretudo, na prática.

\section{Você acha que a questão do "branqueamento" era central nesse processo?}

Minha impressão é que os fazendeiros paulistas teriam contratado trabalhadores azuis ou verdes, de qualquer cor, contanto que fosse factível obrigá-los a recolher o café pelo menor preço possível. Ao mesmo tempo, você tem afirmações, em toda a intelectualidade brasileira do período, de um racismo brutal, e imagino que os fazendeiros compartilhavam 
muitos desses preconceitos. Entretanto, quando ficou difícil importar espanhóis e italianos, os fazendeiros simplesmente ignoraram 20 anos ou mais de histeria antiasiática e começaram a importar japoneses em 1908, aparentemente sem muita ginástica mental.

\section{Barbara Weinstein, em seu novo livro, The color of modernity, ${ }^{58}$ analisa a construção da identidade regional paulista. Em que medida você acha possível relacionar esse grande processo de imigração europeia e asiática com essa concepção de uma identidade paulista peculiar? Você chegou a pensar um pouco nisso?}

Não sei. Peter Eisenberg e eu fizemos um trabalho para um congresso anos atrás, que nunca publicamos, em que queríamos identificar a diferença que a imigração fez em Pernambuco e São Paulo. E chegamos um pouco à conclusão de que é difícil ver a imigração, especificamente, influenciando a história posterior. Esse tipo de questão é complicado porque havia alguns intelectuais, jornalistas, entre outros, na época, expondo argumentos muito explícitos sobre as peculiaridades históricas de São Paulo. Mas o difícil é saber até que ponto essas ideias penetraram no grosso da população de descendentes de italianos e espanhóis em São Paulo. Alguns observadores viam a emergência de uma identidade ítalo- paulista específica nos anos 1920, algo distante da ideologia dominante. Na década posterior, a julgar por Ângelo Trento ${ }^{59}$ e Fábio Bertonha, ${ }^{60}$ o fascismo conseguiu mobilizar uma certa identificação italiana difusa, em São Paulo, mas sem grandes consequências políticas. O Brasil entrou na guerra contra o Eixo sem dificuldades significativas em São Paulo, por exemplo. Uma certa corrente da historiografia sempre insistia na rapidez da assimilação em São Paulo. Há um estudo de José Arthur Rios sobre isso. ${ }^{61} 0$ que aconteceu em três gerações em outros lugares teria acontecido em duas em São Paulo, segundo Rios. É complicada essa questão. Um dado que se usa muito é o pouco emprego de línguas estrangeiras relatado no recenseamento de 1940. Nesse ano, depois de uma longa campanha contra os "quistos" étnicos não assimilados, podemos imaginar de fato uma certa relutância dos recenseados em se identificar como não assimilados ao agente do governo. Temos, portanto, uma imagem de quase todo mundo falando português. Mas estudos posteriores mostram que o uso de dialetos italianos era bastante comum em grupos específicos de imigrantes, mesmo nos anos 50. É a conclusão, por exemplo, do trabalho do antropólogo italiano Carlo Castaldi. ${ }^{62}$ Por outro lado, supõe-se que haveria menos dificuldade entre os três maiores grupos de imigrantes (isto é, italianos, espanhóis e portugueses), todos falantes de línguas neolatinas 
mais ou menos inteligíveis entre si. De qualquer forma, a distância entre o dialeto vêneto e o português não é muito maior do que a distância entre o dialeto vêneto e o italiano oficial, toscano, que relativiza um pouco o significado do rápido desaparecimento do italiano entre os descendentes dos imigrantes. Os três grupos também compartilhavam de uma difusa cultura católica, mediterrânea. Essa situação de São Paulo era, provavelmente, mais fácil para uma certa integração/assimilação do que a situação norte-americana com grupos extremamente distantes em termos culturais, ou mesmo da Argentina, onde havia um número bem maior de imigrantes da Europa Oriental. Tento deixar essa questão um pouco em aberto, esperando que alguém venha a estudá-la com mais precisão. Seria possível pesquisar, creio (sempre pensei em fazer isso, mas nunca me mobilizei de fato), as certidões de casamento, que indicam a nacionalidade dos pais. Uma estatística sempre citada é a do grande número de italianos casando com brasileiras. Mas desconfio que uma grande parte dessas brasileiras fossem filhas de italianos, o que diminuiria o impacto desse tipo de estatística. Seria útil estudar isso com mais precisão. De qualquer forma, acho que todos esses argumentos sobre o regionalismo, inclusive naquelas pesquisas clássicas de Joe Love, John Wirth e Robert Levine, ${ }^{63}$ que enfatizam as identidades regionais ao custo de identidades de classe, são bastante problemáticos. Penso que essas abordagens não são incompatíveis. Identificações regionais existem, sem dúvida, e contam na vida de muitas pessoas. Mas a exclusão de outras determinações, como as de classe ou de etnia, me parece um erro.

\section{Uma pergunta que você sempre faz para as pessoas é: por que não houve, de fato, um partido socialista significativo no Brasil na Primeira República?}

Olha, eu penso nisso há 30, 40 anos, e nunca cheguei a nenhuma conclusão satisfatória. Acho importante, entretanto, notar que essa não é uma questão normalmente colocada pela historiografia brasileira, mas ela surge em função da história comparada. A comparação óbvia é com a Argentina, onde o Partido Socialista exercia uma influência importante. Sim, a repressão no Brasil foi grande... mas, em comparação com a Argentina, o Brasil não leva nenhum prêmio nessa área. Não se trata de experiência prévia, penso, porque poucos argentinos imigrantes parecem ter chegado com um passado socialista significativo. Dá para formular hipóteses sobre a composição da burguesia, a estrutura da indústria e sobretudo a natureza da classe dominante brasileira na época, mas nunca consegui formular uma interpretação que me convencesse. Estou ainda à procura de uma resposta a essa questão... 
Mais recentemente você começou a abordar questões como corporativismo, leis do trabalho, não apenas na Primeira República, mas entrando pelo período Vargas e todo o ambiente intelectual em torno disso. Você foi um dos primeiros historiadores a questionar o senso comum da inspiração fundamental da CLT na Carta del Lavoro fascista italiana e procurou entender a lei brasileira numa perspectiva internacional mais ampla. Como você chegou nesse tema?

Eu queria entrar nessa discussão, e nunca o fiz como gostaria. Mas sempre vejo as origens italianas e fascistas da legislação brasileira, o que levanta a questão da persistência aqui desse sistema. No resto do mundo, essas medidas raramente sobrevivem ao fim do ditador que as instalou. Uma investigação mais detalhada deixou evidente que a verdadeira inspiração era mais difusa que a Carta del Lavoro. Agora, eu nunca achei a pistola com fumaça saindo - the smoking gun - para demonstrar a origem do sistema brasileiro no fascismo italiano, porque nunca consegui descobrir detalhadamente como Evaristo de Morais e Joaquim Pimenta, as pessoas que aparentemente redigiram e inventaram as primeiras medidas corporativistas, agiram dentro do governo Vargas. Evaristo era muito atento a essas questões, mas comentários específicos dele sobre a legislação italiana, eu nunca vi. Outro aspecto incômodo é a existência de um corporativismo de esquerda na época, cujos defensores achavam o corporativismo uma solução para eliminar o que consideravam o desperdício das greves e o caos da luta de classes. Isso parecia fazer um certo sentido numa época em que noções de planejamento econômico e a organização racional do trabalho estavam em voga. Há vários pensadores, especialmente franceses, mas também de outras nacionalidades, que eram ou ainda se consideravam de esquerda e pregavam soluções corporativistas. Mas, realmente, nunca avancei como queria nisso. Há algumas pesquisas mais recentes que vão um pouco nessa direção. Mas acho que ainda resta bastante a fazer. Entretanto, até alguém descobrir a documentação do gabinete de Lindolfo Collor e de outros setores relevantes do Ministério do Trabalho da época, não sei como, no nível muito específico, vamos conseguir responder à questão das origens do corporativismo brasileiro.

\section{Você também tem trabalhado com o tema do "Queremismo" numa perspectiva comparativa...}

Ao que me lembre, entrei nisso por uma sugestão de Leslie Bethell. ${ }^{64}$ Ele me falou uma vez da questão que incluía em suas provas de História da América Latina para alunos na Inglaterra, sobre por que as manifestações de 17 de outubro de 1945 na Argentina tiraram Perón da prisão e efetivamente o colocaram no poder, quando exatamente na mesma época o "queremismo" 
varguista fracassou no Brasil. A resposta curta para explicar esses dois resultados diferentes é: "porque o movimento sindical argentino tinha muito mais consistência, autonomia e força do que o sindicalismo brasileiro do fim do governo Vargas". Claro que há outros fatores, como, por exemplo, o desgaste do governo Vargas depois de 15 anos no poder. Ainda estou trabalhando com essa temática, inclusive com considerações sobre os efeitos a médio e longo prazo desses eventos que pretendo incluir em um livro de ensaios que estou preparando.

\section{É visível seu interesse pelos debates metodológicos. Você levanta questões que poderíamos dizer que frequentemente apontam para uma perspectiva de história comparada. Esse seu interesse pela história comparada vem da sua formação inicial? Ou você o desenvolveu posteriormente?}

Acho que um pouco as duas coisas. Primeiro, nos Estados Unidos, se trata a América Latina, incluindo o Brasil, como um tipo de bloco, o que acaba levantando questões interessantes da perspectiva comparada, ao mesmo tempo que cria confusões significativas. Por outro lado, a própria profissão, com sua organização disciplinar por áreas geográficas, não incentiva muito as comparações internacionais. Acho que todas as historiografias nacionais tendem a considerar a experiência do seu país como única e peculiar, embora haja uma insatisfação crescente entre os historiadores com esse tipo de abordagem. Há um longo debate nos Estados Unidos sobre sua suposta excepcionalidade. Um debate, aliás, que se dá também em relação à história do movimento operário. Mas por lá a discussão historiográfica caminhou em duas ou três direções. Primeiro, a história do movimento operário americano não é tão distante assim da dos movimentos operários europeus no começo do século XX. Acho que, na verdade, a Alemanha é a grande exceção nesse período, com um forte partido socialista ligado a um poderoso movimento sindical. Há semelhanças, por exemplo, das taxas relativamente baixas de sindicalização no começo do século XX entre a Inglaterra, a França e os Estados Unidos. Uma complicação é que num país muito grande, como os Estados Unidos, as estatísticas nacionais às vezes são um pouco enganadoras. Mas essa convicção de que a experiência nacional é incomparável é quase universal, a meu ver. Examinar isso criticamente me parece uma boa tarefa para os historiadores.

\section{Você entende que existe algum tipo de reflexão mais sistemática sobre como realizar uma história comparada?}

Às vezes eu acho que a única coisa interessante que li sobre isso foi um artigo que Marc Bloch publicou no fim dos anos $1920 .{ }^{65} 0$ que existe de observações não muito úteis, 
nessa área, é considerável. Ultimamente foram publicados estudos mais rigorosos. Nas Ciências Sociais há toda uma série de protocolos, e é muito comum esse tipo de pesquisa. Mas as críticas recentes às comparações que naturalizam o Estado nacional ao tomá-lo como a unidade de comparação quase automática também me parecem muito pertinentes e convincentes. Mas a história comparada é um campo que oferece, pelo menos, sugestões interessantes. Não sei se dá para comprovar muita coisa com comparações, mas elas frequentemente nos ajudam a impedir generalizações insustentáveis. E o que acho mais interessante é que a comparação muitas vezes levanta questões que a historiografia nacional ignora. Essa utilidade das comparações me parece inquestionável.

No mundo todo, os anos 90 assistiram a um forte questionamento da História Social e, em particular, da Histórica Social do Trabalho. Há centenas de debates nesse período, especialmente no mundo anglo-saxão. No entanto, no Brasil, o linguistic turn não foi tão influente na área do trabalho. Por quê?

É interessante. Sempre achei que o pós-modernismo não pegou muito no Brasil porque as contradições sociais são tão óbvias - na forma de mendigos infantis batendo na janela do seu carro nos cruzamentos, por exemplo - que era muito difícil interpretar isso como apenas uma construção linguística. [risos] Mas ao mesmo tempo não me parece que a experiência do linguistic turn fosse totalmente negativa. Certamente os historiadores, hoje em dia, têm muito mais sensibilidade para questões da linguagem do que tinham 30 ou 40 anos atrás.

\section{No nosso campo há toda essa discussão contemporânea sobre Global Labour History, História Global do Trabalho, toda uma crítica ao nacionalismo metodológico. Você já mencionou rapidamente que considera essa crítica algo interessante, mas como você avalia especificamente todo esse debate? Particularmente, como você vê o Brasil dentro desse debate?}

Penso que a primeira questão é a dificuldade de fazer Global Labour History segundo os cânones da historiografia. Se os historiadores valorizam o contato com fontes primárias e uma certa sensibilidade para a mudança no tempo, muitos estudos nessa perspectiva me parecem ser bastante atemporais. Além disso, dominar a historiografia de um país é complicado - imaginem de três ou quatro, mesmo com línguas que o historiador consegue ler. Então mantenho uma atitude agnóstica em relação a certas formulações da história global. Acho extremamente interessante, estimulante, mesmo chegando às vezes a conclusões bastante esperadas, com 
afirmações que não inovam enormemente. E os estudos mais convincentes me parecem ser os mais específicos. Talvez seja mais útil em algumas áreas, como nos estudos da escravidão, embora eu seja muito cético quanto à existência de uma entidade chamada a escravidão brasileira, que começaria muito antes da existência do Estado brasileiro, duraria séculos, sobre um território imenso, e ao mesmo tempo teria qualidades suficientemente diferentes da experiência em outros lugares para justificar o uso do objeto "a escravidão brasileira". 0 mesmo se poderia dizer de um objeto chamado "o movimento operário brasileiro na Primeira República", com características homogêneas apesar das imensas variações. De toda forma, confesso, estou menos entusiasmado do que algumas pessoas com a História Global do Trabalho. Ao mesmo tempo, a perspectiva comparada sempre me parece útil, sobretudo como uma maneira de criticar o provincianismo das historiografias nacionais. Penso que a utilidade desse tipo de perspectiva vai variar um pouco, dependendo do tipo de questão que você quer estudar. Um problema para as pesquisas de história global no Brasil é o fato de que o número de brasileiros que trabalha com tópicos não brasileiros, na historiografia pelo menos, é muito pequeno. Eu tive três bons orientandos argentinos. Mas isso foi muito mais em função do desastre das universidades argentinas nos anos 70 e 80 do que qualquer outra coisa. Mas acho que conhecer Norberto Ferreras, ${ }^{66}$ Dora Barrancos ${ }^{67}$ e Andreas Doeswijk ${ }^{68}$ foi útil para os nossos alunos. Sempre acho que deveríamos ter incentivado um maior intercâmbio com a América Latina. Por outro lado, certamente, a historiografia brasileira, mesmo se restringindo a uma história muito especificamente brasileira, agora está sendo escrita com perspectivas internacionais muito mais amplas e profundas do que 20 anos atrás, 0 que é um avanço inquestionável.

Uma questão mais específica sobre o mundo da academia, já que você viveu as mudanças do mundo universitário brasileiro desde os anos 70, e, pela sua própria trajetória, você tem condição de colocá-las numa perspectiva mais global. Na sua trajetória, percebemos uma forte ênfase na importância de uma certa infraestrutura para a pesquisa na universidade: bibliotecas, arquivos, etc. Como você avalia os últimos anos da academia brasileira e uma certa tendência ao que poderíamos chamar de produtivismo, o que muitos chamam ironicamente de "geração Lattes", em comparação com um período anterior em que o tempo da produção era mais longo? Como você avalia isso, pensando na sua experiência no Brasil?

O que mais me impressiona, obviamente, é a enorme expansão das universidades e, certamente, a profissionalização entre os historiadores. Isso é inquestionável. Agora, acho 
lamentável a incorporação de padrões de mensuração acadêmica que vêm basicamente das ciências exatas. Meu exemplo predileto é a Fapesp, exigindo, no caso de subsídio para o livro de um ex-orientando (portanto uma pessoa com quem o orientador não tem mais relação institucional), que o dinheiro viesse para a conta do orientador. Minha teoria é que isso tem a ver com o catolicismo, que nunca incentivou exatamente contatos diretos entre fiéis e Deus e, assim, usa uma série de categorias intermediárias - sacerdotes, santos, anjos etc. Os ex-orientandos e o orientador (agora canonizado) estariam, portanto, nessa situação ao lidar com 0 Deus, no caso, a Fapesp... [risos] Mas, de fato, o problema está na aplicação do modelo das ciências exatas, onde as relações são significativamente diferentes. 0 orientador, nas exatas, muitas vezes define o tema de pesquisa do aluno e até publica os resultados com o nome dele no artigo [risos]. Esse mesmo sistema também valoriza uma série de exigências. Por exemplo, acho estranhíssimo valorizar tanto, especialmente para historiadores no Brasil, a publicação em inglês. Pelo contrário, os historiadores estrangeiros especialistas em Brasil fazem questão de tentar conseguir publicar seus livros em português, porque o público, para obras sobre a História do Brasil, está aqui. De certa forma, o Brasil está incorporando os piores elementos do sistema norte-americano.

Uma última questão. Um balanço da historiografia social do trabalho no Brasil da qual você foi um dos protagonistas - nas últimas quatro décadas indica uma mudança na visão do papel dos trabalhadores e dos grupos subalternos em geral na história do país. Poderíamos dizer talvez que, de uma visão profundamente pessimista sobre o papel dos trabalhadores na história, passamos a ter uma visão mais "otimista", que valorizou a participação e a ação desses setores sociais. E essa visão "otimista" estava implicitamente vinculada a determinadas visões e posições políticas, que parecem estar em crise profunda neste momento. Como você vê o futuro da história social do trabalho no Brasil e quais os principais desafios que teremos de enfrentar numa conjuntura que parece ser a mais adversa dos últimos 30 anos?

Acho isso relativo. Ao que vejo, por exemplo, a guinada à direita nos Estados Unidos nas últimas décadas não teve consequências fatais, nem necessariamente muito graves, para a historiografia social desse tipo naquele país. Talvez haja uma distância maior entre o momento político e o trabalho dos historiadores do que a pergunta sugere. Mas historiadores são péssimos profetas. É fácil, em junho de 2016, exagerar um pouco as consequências perniciosas da conjuntura para o nosso trabalho. De qualquer forma, a legitimação da história do trabalho e 
dos trabalhadores como um campo autêntico e significativo dentro da historiografia brasileira é um grande avanço. Os trabalhos produzidos nos últimos anos, rigorosos, com forte base empírica, me parecem impressionantes por qualquer padrão. 0 uso de novas fontes - História Oral, arquivos patronais e policiais, por exemplo - permitiu um aprofundamento dos trabalhos que teria sido difícil de imaginar algumas décadas atrás.

Em termos de desafios, minhas sugestões sobre pesquisas futuras tendem a ser bastante específicas. Por exemplo, o alargamento da atenção dos historiadores para categorias geralmente ignoradas - as lutas de trabalhadores rurais, para citar um caso bastante óbvio, seria importante. E qualquer esforço para derrubar divisões arbitrárias na historiografia seria bem vindo: trabalho escravo/trabalho livre, história do trabalho/história da imigração seriam duas das mais evidentes separações desse tipo. No meu campo de estudos específico, é curiosa a falta de informação sobre o movimento operário de São Paulo nos anos 1920. Às vezes parece que os historiadores que começam seus trabalhos com o fim do século XIX acabam cansando e parando por volta de 1917 ou 1920, enquanto outros historiadores começam rigorosamente em 1930. Uma lista bastante arbitrária de outros estudos que eu gostaria de ler vai incluir uma história interna das medidas trabalhistas dos anos 1930 e uma avaliação do significado da imigração subsidiada para os próprios imigrantes. É apenas coincidência que grupos que se saíram notoriamente bem em São Paulo - sírios e libaneses, judeus, armênios - não vieram com a passagem paga e não passaram pelas fazendas?

Outros tópicos poderiam ser os efeitos nos países europeus do retorno do Brasil de uma parte significativa dos seus imigrantes, ou a construção em São Paulo, entre grupos claramente divididos por classe e origem regional, de noções de "comunidades" ou "colônias", supostamente homogêneas e externamente delimitadas, que viraram, nessas interpretações, atores coletivos com objetivos comuns. Neste caso, há uma visão ideal sustentada por certos membros da categoria confundida com o que efetivamente se passou entre os imigrantes, e tudo isso merece mais atenção dos historiadores.

E, por último, eu gostaria de ver mais estudos das vidas transnacionais de imigrantes. É verdade que agora temos bons livros tratando de alguns líderes militantes de origem estrangeira que atuaram em vários países, mas precisamos de mais. Por exemplo, seria ótimo poder ler um estudo sobre a carreira brasileira de Antun Saadeh, que praticamente inventou o estado da Síria durante os anos que passou em São Paulo nas décadas de 1920 e 1930 (quando a França governava os ex-territórios otomanos do Líbano e Síria). Existe uma certa literatura disponível em inglês e francês que trata de Saadeh (um personagem altamente controvertido por vários motivos), embora os autores estejam preocupados com os escritos de Saadeh sobre o Oriente Médio e não com suas experiências na emigração. ${ }^{69}$ Há uma edição das obras de 
Saadeh publicada em Beirute em 16 volumes (e mais quatro de correspondência), obviamente em árabe. Tanto Antun quanto o pai dele participaram intensamente dos debates animados conduzidos na imprensa de língua árabe de São Paulo e de Buenos Aires. 0 que sobreviveu desses jornais e revistas é uma incógnita, mas nunca vi nada desse tipo em nenhuma coleção pública em São Paulo. Há referências, por exemplo, a um artigo publicado por Saadeh numa revista de Beirute sobre a Revolução de 1930 no Brasil, que deveria ser, no mínimo, uma curiosidade. A capa de uma biografia recente ${ }^{70}$ mostra Saadeh por volta de 1926 no Belvedere do Parque Trianon na Avenida Paulista, demolido para a construção do MASP. Na foto ele está olhando a cidade com um ar pensativo. 0 que será que passava pela sua cabeça?

\section{NotAs}

1 Henry Wallace (1888-1965) foi vice-presidente dos EUA entre 1941 e 1945, no governo de Franklin Roosevelt. Favorável ao New Deal, ao fim da segregação e a relações mais amenas com a URSS, foi preterido pelo Partido Democrata nas eleições de 1944 em favor de Harry Truman. Em 1948 disputou as eleições presidenciais pelo Partido Progressista, mas não teve êxito.

2 Iniciada no governo Kennedy no começo dos anos 1960, logo após a Revolução Cubana, e estendendo-se por cerca de uma década, a Aliança para o Progresso foi um programa dos EUA destinado a fomentar o desenvolvimento dos países latino-americanos, visto pelos estadunidenses como fundamental para conter o avanço do comunismo na região.

3 Ex-diretor do Center for Latin American and Caribbean Studies (University of Illinois) e autor de diversos livros sobre o Brasil, entre eles A locomotiva: São Paulo na Federação Brasileira (Rio de Janeiro: Paz e Terra, 1982).

4 Historiador especialista em história do Brasil, conhecido por suas pesquisas sobre o catolicismo, destacando-se Milagre em Joaseiro (3a ed. São Paulo: Companhia das Letras, 2014).

5 Autor de Burocracia e sociedade no Brasil colonial (São Paulo: Perspectiva, 1979) e de vários outros livros.

6 Autor de diversos estudos sobre a América Latina e o Brasil, entre outros An introduction to Brazil (New York: Columbia University Press, 1963).

7 Autor de Padrões raciais nas Américas (Rio de Janeiro: Civilização Brasileira, 1967) e outros estudos.

8 Dirigido por Philippe de Broca e lançado em 1964, O homem do Rio (L'Homme de Rio) tinha diversas cenas filmadas no Rio de Janeiro, Brasília e Amazônia.

9 Dirigido por Marcel Camus e lançado em 1959, Orfeu Negro (Orphée Noir) tinha como cenário uma favela carioca. A trilha sonora era de Tom Jobim e Luis Bonfá.

10 Ver Michael Hall, Attitudes toward immigration in the Brazilian Empire, 1822-1889 (Master of Arts Thesis. New York: Columbia University, 1965).

11 Ver José Honório Rodrigues, Os estudos brasileiros e os brazilianists, Revista de História, vol. 54, n. 107, 1976. 
12 Agência dos EUA dedicada à diplomacia pública.

13 Autor de The Brazilian corporative state and working-class politics (Berkeley and Los Angeles: University of California Press, 1977).

14 Além de suas muitas publicações sobre a História brasileira, entre as quais Modernização sem mudança: a indústria açucareira de Pernambuco, 1840-1910 (Rio de Janeiro: Paz e Terra, 1977), originalmente apresentada como tese de doutorado na Columbia University, Eisenberg teve importante papel, nos anos 1970 e 1980, na implantação do Programa de Pós-Graduação em História da Unicamp.

15 Fundada em 1920 e sediada em Nova York, trata-se de uma organização não partidária e sem fins lucrativos cuja atuação se concentra na defesa de direitos e liberdades individuais.

16 Professor de Ciência Política na Unicamp e posteriormente na USP (onde atuou na fundação do Núcleo de Estudos da Violência) e em outras universidades no exterior. Atualmente é membro do Alto Comissariado para os Direitos Humanos da ONU.

17 Autor de Anarquistas e comunistas no Brasil, 1900-1935 (Rio de Janeiro: Nova Fronteira, 1973);

18 Professor do Departamento de História da Unicamp do começo dos anos 1980 até 2002, quando assumiu o cargo de assessor especial da Presidência da República. Autor de textos sobre, entre outros temas, a história da esquerda, intelectuais e o movimento operário brasileiro.

19 Zeferino Vaz foi reitor da Unicamp entre 1966 e 1978.

20 Professora de Ciência Política com doutorado pela Stanford University.

21 As atas do congresso saíram em dois volumes, organizados por Paulo Sérgio Pinheiro: O Estado autoritário e os movimentos populares (Rio de Janeiro: Paz e Terra, 1980) e Trabalho escravo, economia, e sociedade (Rio de Janeiro: Paz e Terra, 1983).

22 Nos anos 1980, foi professor de Sociologia na USP. Autor de Quando novos personagens entraram em cena: experiências e lutas dos trabalhadores da grande São Paulo (1970-1980) (Rio de Janeiro: Paz e Terra, 1988). Faleceu em 1988.

23 Docente do Departamento de Sociologia da USP. Escreveu, especialmente nos anos 1980 e 1990, diversos textos sobre os trabalhadores brasileiros.

24 Docente do Departamento de Sociologia da USP. Assim como Eder Sader e Maria Célia Paoli, produziu influentes estudos sobre os movimentos sociais brasileiros dos anos 1970 e 1980.

25 Fundado em 1976, o Centro de Estudos de Cultura Contemporânea (Cedec) reunia pesquisadores de diferentes disciplinas e em seus primeiros anos produziu inúmeros trabalhos sobre os novos movimentos sociais.

26 Socióloga, docente da Faculdade de Educação da USP.

27 Cientista político, ex-docente da USP e autor de diversos livros, destacando-se sua produção sobre o populismo. Foi ministro da Cultura no governo Fernando Henrique Cardoso.

28 Ver Silvia Magnani, O movimento anarquista em São Paulo (São Paulo: Brasiliense, 1982).

29 Ver Michael Hall, Immigration and the early São Paulo working class, Jahrbuch fuer Geschichte von Staat, Wirtschaft und Gesellschaft Lateinamerikas, v. 12, 1975. 
30 Michael Hall e Paulo Sérgio Pinheiro, Alargando a história da classe operária: organização, lutas e controle, Remate de Males, n. 5, 1985.

310 historiador estadunidense Herbert Gutman escreveu o clássico The black family in slavery and freedom: 1750-1925 (New York: Pantheon, 1975), obra importante na renovação da História Social do Trabalho nos EUA. Especialmente sobre a História do Trabalho, Gutman publicou Work, culture and society in industrializing America: essays in American working-class and social history (New York: Knopf, 1978) e Power and culture: essays on the American working class (New York: New Press, 1987).

32 Hill foi um dos membros do Grupo de Historiadores do Partido Comunista da Grã-Bretanha. Algumas de suas obras, como 0 mundo de ponta-cabeça: ideias radicais durante a Revolução Inglesa de 1640 (São Paulo: Companhia das Letras, 1987), tornaram-se referências obrigatórias para os praticantes da "história vista de baixo".

33 Antropóloga, é professora emérita do Departamento de Antropologia Cultural e Social da Universidade Autônoma de Barcelona. Foi professora na Unicamp nos anos 1970. É autora de Cafeicultura: homens, muIheres e capital, 1850-1980 (São Paulo: Brasiliense, 1986).

34 Michael Hall e Paulo Sérgio Pinheiro, A classe operária no Brasil: 1889-1930, v. 1, O movimento operário (São Paulo: Alfa-Ômega, 1979) e v. 2, Condições de vida e de trabalho, relações com os empresários e o Estado (São Paulo: Brasiliense/Campinas: Funcamp, 1981).

35 História das lutas sociais no Brasil (São Paulo: Edaglit, 1962)

36 Sindicato e Estado (São Paulo: Dominus, 1966).

37 Verena Stolcke e Michael Hall, Introdução do trabalho livre nas fazendas de café de São Paulo, Revista Brasileira de História, n. 6, 1983.

38 Autor, entre outros livros, de Os últimos anos da escravatura no Brasil, 1850-1888 (Rio de Janeiro: Civilização Brasileira, 1975).

39 Michael Hall and H. Spalding, The urban working class and early Latin American labour movements, 1880-1930, in Cambridge History of Latin America, v. 4 (Cambridge: Cambridge University Press, 1986).

40 Historiador estadunidense falecido em 2011, considerado um dos fundadores da nova história do trabalho em seu país. Autor de Workers' control in America: studies in the history of work, technology, and labor struggles (New York: Cambridge University Press, 1979). Foi professor da Universidade de Yale.

41 Historiadora estadunidense especialista em América Latina. Publicou diversos textos sobre o Brasil, entre eles (Re)formação da classe trabalhadora no Brasil (1920-1964) (São Paulo: Cortez, 2000). Atualmente é professora da Universidade de Nova York.

42 Historiador britânico especialista em América Latina, sobretudo em peronismo, escreveu entre outros livros Resistance and integration: peronism and the Argentine working class, 1946-1979 (Cambridge: Cambridge University Press, 1988). Atualmente é professor da Universidade de Indiana.

43 Robert Slenes, professor do Departamento de História da Unicamp, autor de Na senzala, uma flor: esperanças e recordações na formação da família escrava (Brasil Sudeste, século XIX) (Rio de Janeiro: Nova Fronteira, 1999).

44 Silvia Hunold Lara, professora do Departamento História da Unicamp. Um de seus livros recentes é Fragmentos setecentistas: escravidão, cultura e poder na América Portuguesa (São Paulo: Companhia das Letras, 2007). 
45 Sidney Chalhoub é, desde 2015, professor da Universidade de Harvard nos Estados Unidos. Foi professor do Departamento de História da Unicamp, e é autor, entre vários outros livros, de Visões da liberdade: uma história das últimas décadas da escravidão na Corte (São Paulo: Companhia das Letras, 1990).

46 Maria Clementina Pereira Cunha, professora do Departamento de História da Unicamp e autora, entre outros livros, de Carnavais e outras f(r)estas (Campinas: Editora da Unicamp, 2002).

47 Professor do Departamento de História da Unicamp e autor de diversos textos sobre o movimento operário brasileiro, especialmente o da Primeira República, incluindo sua tese de doutoramento Le sindicalisme "amarelo" à Rio de Janeiro (1906-1930) (Paris: Université Paris 1, 1986).

48 E. P. Thompson, A economia moral da multidão inglesa no século XVIII, in Costumes em comum (trad. Rosaura Eichemberg. São Paulo: Companhia das Letras, 1998). Nos anos 1980, a versão mais utilizada no Brasil era La economia 'moral' de la multitud en la Inglaterra del siglo XVIII, in Tradición, revuelta y consciencia de clase (Barcelona: Crítica, 1979).

49 A multidão na história (Rio de Janeiro: Campus, 1991), que circulava no Brasil desde os anos 1970 em espanhol: La multitud en la historia (Buenos Aires: Siglo Veintiuno, 1971).

50 Eighteenth-century English society: class struggle without cass?, Social History, v. 3, n. 2, 1978. Nos anos 1980, a versão mais utilizada no Brasil era La sociedad inglesa del siglo XVIII: ¿Lucha de clases sin clases?, in Tradición, revuelta y consciencia de clase (Barcelona: Crítica, 1979).

51 Boris Fausto, A Revolução de 1930 (São Paulo: Brasiliense, 1970).

52 Mauricio Font, Coffee and transformation in São Paulo, Brazil (Lanham, Maryland: Lexington Books, 2010), p. 142-144.

53 Michael Hall, Imigrantes na cidade de São Paulo in Paula Porta (org.), História da cidade de São Paulo, vol. III (São Paulo: Paz e Terra, 2004) e Entre a etnicidade e a classe em São Paulo, in Maria Luiza Tucci Carneiro, Frederico Croci e Emilio Franzina (orgs), História do trabalho e histórias da imigração (São Paulo: Edusp, 2010).

54 Luiz Carlos Bresser Pereira, Origens étnicas e sociais do empresário paulista, Revista de Administração de Empresas, vol. 4, 1964.

55 José de Souza Martins, Empresários e trabalhadores de origem italiana no desenvolvimento industrial brasileiro entre 1880 e 1914: o caso de S. Paulo, Dados, vol. 24, nº 2, 1981.

56 Verena Stolcke e Michael Hall, A introdução do trabalho livre nas fazendas de São Paulo, Revista Brasileira de História, n. 6, 1983.

57 Ver, entres outros, o influente e controverso artigo de Gopalan Balachandran, Making coolies, (un)making workers: "globalizing" labour in the late-19th and early-20th centuries, Journal of Historical Sociology, 24: 3 (2011)

58 Barbara Weinstein, The color of modernity: São Paulo and the making of race and nation in Brazil (Durham: Duke University Press, 2015).

59 Angelo Trento, 'Donde haya un italiano, allí estará la bandera tricolor': la penetración del fascismo entre los emigrantes en el Brasil, in Eugenia Scarzanella (org.), Fascistas en América del Sur (Buenos Aires: Fondo de Cultura Económica, 2007).

60 João Fabio Bertonha, O fascismo e os imigrantes italianos no Brasil (Porto Alegre: Edipucrs, 2001). 
61 Jose Arthur Rios, Aspectos políticos da assimilação do italiano no Brasil (São Paulo: Fesp, 1959).

62 Carlo Castaldi, 0 ajustamento do imigrante à comunidade paulistana: estudo de um grupo de imigrantes italianos e de seus descendentes, in Bertram Hutchinson (org.), Mobilidade e trabalho (Rio de Janeiro: Centro Brasileiro de Pesquisas Educacionais, 1960).

63 Joseph Love, A locomotiva: São Paulo na federação brasileira: 1889-1937 (Rio de Janeiro: Paz e Terra, 1982); John Wirth, O fiel da balança: Minas Gerais na federação brasileira (1889-1937) (Rio de Janeiro: Paz e Terra, 1982); e Robert Levine, A velha usina: Pernambuco na federação brasileira (1889-1937) (Rio de Janeiro: Paz e Terra, 1980).

64 Historiador inglês, organizador da Cambridge History of Latin America.

65 Marc Bloch, Pour une histoire comparée des sociétés européennes, Revue de Synthèse Historique, 46, 1928.

66 Norberto Ferreras, O cotidiano dos trabalhadores de Buenos Aires (1990-1920) (Niterói: EdUff, 2005).

67 Dora Barrancos, La escena iluminada: ciências para trabajadores, 1890-1930 (Buenos Aires: Plus Ultra, 1996).

68 Andreas Doeswijk, Los anarco-bolcheviques rioplatenses, 1917-1930 (Buenos Aires: CEDINCL, 2013).

69 Fouzieh Alchehazeh Alfrihat, La conception de l'état et les fondements du pouvoir selon Antun Saadeh, Thèse de Doctorat (Paris: Université Paris X, 1995).

70 Salim Mlujais, Antun Saadeh: a biography (Beirute: Kutub, 2004). 